\title{
The business reason in the 2020 tax reform
}

\section{La razón de negocios en la reforma fiscal 2020}

\author{
BÁRCENAS-PUENTE, José Luis广๋* \& ANDRADE-OSEGUERA, Miguel Ángel
}

Universidad Tecnológica del Suroeste de Guanajuato

ID $1^{\text {st }}$ Author: José Luis, Bárcenas-Puente / ORC ID: 0000-0002-1051-8861, Researcher ID Thomson: S-8603-2018, CVU CONACYT ID: 743962

ID $1^{\text {st }}$ Coauthor: Miguel Ángel, Andrade-Oseguera / ORC ID: 0000-0002-7926-9162, Researcher ID Thomson: S-65862018, CVU CONACYT ID: 509374

DOI: $10.35429 / J B A B .2020 .7 .4 .20 .32$

Received September 22, 2020; Accepted December 30, 2020

\begin{abstract}
When a person decides to start a business, whatever legal figure he or she uses; invariably the goal will always be profit. In this regard, the debate is that the social function should actually be the end and generation of profits, the consequence; in any case, companies are expected to have an infrastructure, capital, employees, processes, a stay and location in the market, etc. If a business is created with an apparent or simulated turn, disguising tax evasion ins and outs, it must necessarily face administrative and criminal consequences. However, as has been ventilated on other occasions, tax planning does not involve any crime; premise that is more important than ever in this tax reform of 2020, in which a prosecution against tax advisers has been legalized, equating their professional work with organized crime, creating audit procedures that govern the free exercise of the profession, like says Article 5. Constitutional. The international trend, namely the BEPS Project, has been to monitor and punish simulation; however, the incorporation of these measures into the Mexican tax system appears to be exceeded and inappropriate.
\end{abstract}

Business, Simulation, Advice

\begin{abstract}
Resumen
Cuando una persona decide emprender un negocio, sea cual sea la figura jurídica que utilice; invariablemente el objetivo será siempre el lucro. Al respecto, el debate consiste en que la función social debiera ser en realidad el fin y la generación de utilidades, la consecuencia; en cualquier caso, se espera que las empresas tengan una infraestructura, capital, empleados, procesos, una permanencia y ubicación en el mercado, etc. Si un negocio se crea con un giro aparente o simulado, disfrazando intensiones de evasión fiscal, necesariamente debe enfrentar consecuencias administrativas y penales. Sin embargo, como se ha ventilado en otras ocasiones, la planeación fiscal no implica delito alguno; premisa que resulta más importante que nunca en esta reforma fiscal de 2020, en la que se ha legalizado una persecución hacia los asesores fiscales, equiparando su labor profesional a la delincuencia organizada, creando para ello procedimientos de fiscalización que coartan el libre ejercicio de la profesión, consagrado en el artículo $5^{\circ}$. Constitucional. La tendencia internacional, concretamente el Proyecto BEPS, ha sido fiscalizar y castigar la simulación; no obstante, la incorporación de estas medidas al sistema fiscal mexicano parece excedida e inapropiada.
\end{abstract}

Negocio, Simulación, Asesoría

Citation: BÁRCENAS-PUENTE, José Luis \& ANDRADE-OSEGUERA, Miguel Ángel. The business reason in the 2020 tax reform. Journal-Business Administration -Marketing; Accounting. 2020. 4-7: 20-32

\footnotetext{
* Correspondence to Author (email: jlbarcenasp@utsoe.edu.mx)

$\dagger$ Researcher contributing as first author.
} 


\section{Introduction}

The common concerns of those who start a business should refer to the probability of success of the product or service to be offered; the most favorable location of the premises; select distribution channels; search for suppliers; suitable advertising media, etc. In other words, the tax issue should not be part of your concerns, and yet it is. The question to the accountant is frequent, before anything else, How much would be paid in taxes? Or, would a lot of taxes be paid for such a business?

This may be due, on the one hand, to how expensive it can be to maintain a business with respect to the payment of contributions, in addition to the acts of nuisance (or terrorism) that are sometimes used by the tax authority; but, on the other hand, one cannot deny, resistance to payment, to detach from something, innate in the human being, what many call "culture of nonpayment", exacerbated by the uncertain destination of contributions, such as conceived by the majority of the population. This reflection helps to put in context the topic that is intended to be addressed in this material. Thus, the aspects that should concern the budding entrepreneur, such as those mentioned at the beginning of this section, constitute the business reason; whose concept attempts to define the Fiscal Code of the Federation, which will be analyzed.

In short, any action or activity that does not pursue the business reason but rather some tax interest (evasion) is considered simulation and the 2020 tax reform condemns it. Through this work, the concept of business reason and the fight against simulation are analyzed, with the customary critical stamp, addressing questions such as: What implications does the criminalization of the various simulation cases have? Is the incorporation of international control measures adequate? to the Mexican financial system in an economy hit by the crisis? Is the criminalization of tax advice based on the 2020 tax reform? Can fiscal planning still be feasible in this time of persecution?

It is important to clarify that the position of this material is not the promotion of simulation; but rather the exposition of its implications, excesses, absurdities and abuses that the fiscal authority will undoubtedly commit, in the confused line of the "fight against corruption" implemented by the current government that we suffer.

\section{The concept of business reason.}

To date, there is no definition of business reason in law or doctrine. The new article 5-A of the Federal Tax Code includes in one of its paragraphs an "attempt" to define it that leaves more doubts than solutions. Therefore, we will resort to the interpretation of the basic postulates of the Financial Information Standards (NIF), specifically the following:

Thus, NIF A-2 Basic Postulates Economic Substance, provides:

"The economic substance must prevail in the nature of the operation over its legal form, as well as in the accounting recognition of transactions, internal transformations and other events that economically affect an entity." (Mexican Council of Financial Information Standards, AC, 2020)

(...) The reflection of the economic substance must prevail in the accounting recognition in order to incorporate the effects derived from the transactions, internal transformations and other events that economically affect an entity, in accordance with its economic reality and not only in attention to its legal form, when one and the other do not coincide. Consequently, priority must be given to the fund or economic substance over the legal form.

This is due to the fact that the legal form of an operation may have a different appearance than its true economic background and, consequently, not adequately reflect its impact on the economic-financial situation. Therefore, legal formalities must be analyzed in an appropriate context, in the light of economic substance, so that they do not misrepresent it and thus distort accounting recognition. (Mexican Council of Financial Information Standards, AC, 2020).

On the other hand, in the same work, the postulate Economic Entity establishes:

The economic activities of the entity combined with its resources determine its economic value, regardless of the individual value of said elements. 
The integrated set can be made up of tangible and intangible assets, working capital, intellectual capital and workforce, business knowledge, contracts that ensure the obtaining of resources and the generation of economic benefits, and the processes strategic, operational and resource management managers, among others. (Mexican Council of Financial Information Standards, AC, 2020).

For its part, the Business in Progress postulate considers:

It is assumed that the activity of the economic entity will continue foreseeably in the future. When evaluating whether the presumption of going concern is appropriate, management will take into account all the information that is available for the future, which should cover at least, but not limited to, the following twelve months from the balance sheet date. . The degree of detail of the considerations will depend on the facts that arise in each case. When the entity has a history of profitability, as well as easy access to sources of financial resources, it can be concluded that the ongoing business base is adequate, without making a detailed analysis. In other cases, it may be necessary for management, to satisfy itself that this foundation is adequate, to consider a wide range of factors related to current and expected profitability, debt repayment schedule, and potential sources of resources to replace. current sources of financing. (Mexican Council of Financial Information Standards, AC, 2020).

These postulates, completely accounting in nature, when referring to the way in which businesses are conceived (called "economic entities"; they provide ideas to understand the concept of business reason, such as:

a. It speaks of an economic substance, which is above the legal nature of the person who carries out the transactions, and this may be different from such substance or economic fund.

b. The economic value of an entity is determined by its economic activities combined with its resources.

c. Said combination, in turn, is made up of tangible and intangible assets; working capital; intellectual capital and labor force; business knowledge; contracts to obtain resources; and strategic, operational and administrative management processes, among others. d. Finally, it is presumed that an entity will remain beyond twelve months; even more so if the profitability levels have been as expected.

It means then that these aspects make up a business reason, that is; have a substance or economic fund, carry out activities with a combination of resources (human, financial, material and technical; as established by administrative theory), and also have a permanence in their operations. Let us now explore the new article 5-A of the Federal Tax Code, not only for purposes of analyzing the concept of business reason, but in its entirety, since with this article the reform on the subject at hand begins.

Article 5.-A. Legal acts that lack a business reason and that generate a direct or indirect tax benefit will have the tax effects that correspond to those that would have been carried out to obtain the economic benefit reasonably expected by the taxpayer. (Fiscal Code of the Federation, 2020).

This first paragraph states that legal acts must have a business reason; otherwise and obtain a tax benefit (defined below); there will be tax effects (will be taxed) on the expected economic benefit (profit),

In the exercise of its powers of verification, the tax authority may presume that the legal acts lack a business reason based on the facts and circumstances of the taxpayer known under such powers, as well as the assessment of the elements, the information and documentation obtained during them. Notwithstanding the foregoing, said tax authority may not ignore the aforementioned legal acts for tax purposes, without first disclosing said situation in the last partial act referred to in section IV, article 46 of this Code, in the Official letter of observations referred to in section IV of article 48 of this Code or in the provisional resolution referred to in section II of article 53-B of this Code, and the periods referred to in the previous articles have elapsed, so that the taxpayer manifests what is convenient for him and provides the information and documentation tending to disprove the aforementioned presumption. (Fiscal Code of the Federation, 2020). 
It is mentioned in this paragraph that the authority may presume the absence of a business reason when, in the exercise of its powers of verification, the circumstances make it suppose; for which he must make known to the taxpayer said presumption in the last partial act and the deadlines have elapsed for him to present evidence that disproves the assumption.

Before the issuance of the last partial record, the official letter of observations or the provisional resolution referred to in the previous paragraph, the tax authority must submit the case to a collegiate body made up of officials of the Ministry of Finance and Public Credit the Tax Administration Service, and obtain a favorable opinion for the application of this article. If the opinion of the collegiate body is not received within a period of two months from the presentation of the case by the tax authority, it will be understood to have been carried out in the negative sense. The provisions relating to the aforementioned collegiate body will be made known through general rules issued by the Tax Administration Service for this purpose. (Fiscal Code of the Federation, 2020).

Before the mention in the last partial record, according to this paragraph, the tax authority must submit the case to a collegiate body made up of officials from the SAT and the SHCP itself (will there be technical capacity, impartiality and probity in said collegiate body ?), which will decide, if not to do so within two months, a negative answer is understood and this article will not apply.

The tax authority may presume, unless proven otherwise, that there is no business reason, when the reasonably expected quantifiable economic benefit is less than the tax benefit. Additionally, the tax authority may presume, unless proven otherwise, that a series of legal acts lacks a business reason, when the reasonably expected economic benefit could be achieved through the performance of a smaller number of legal acts and the tax effect of these would have been more burdensome. (Fiscal Code of the Federation, 2020).

It is in the presumption referred to in this paragraph, where an attempt is made to give a definition, for the tax authority at least, of business reason.
By saying that there is no business reason when the reasonably expected quantifiable economic benefit is less than the tax benefit, we can interpret the opposite sensu that there is only a business reason when the tax benefit is less than the economic benefit. In other words, and taking into account what has been analyzed through the NIF, the generation of profits must prevail over any tax benefit, understood as the following paragraph establishes:

Any reduction, elimination or temporary deferral of a contribution are considered tax benefits. This includes those achieved through deductions, exemptions, nontaxation, non-recognition of a profit or accumulative income, adjustments or absence of adjustments to the taxable base of the contribution, the accreditation of contributions, the re-characterization of a payment or activity, a change of tax regime, among others. (Fiscal Code of the Federation, 2020).

When defining tax benefits, the legislator does take pains and precisely reflects what according to the doctrine, tax planning seeks: Reduction, elimination or temporary deferral of a contribution; only that to achieve this, it does not distinguish whether the taxpayer uses lawful acts, such as tax planning, or illegal acts, such as evasion and fraud; which clearly tells us that in the eyes of the authorities, tax planning is also a crime. If we continue reading, we detect an unfortunate wording to say the least, when this is established, it includes those achieved through deductions, exemptions, not substitutions, (...), the accreditation of contributions, (...) a change in tax regime, among others.

That is to say, is it not legal to make deductions? Is it not legal to apply exemptions? Is it not possible that a taxpayer is not subject to this or that contribution or assumption? Is the crediting of contributions not legal? Is the change of tax regime not legal or feasible either? These assertions, as they are written, are excessive and contradict the legal provisions that allow deductions, exemptions, tax bases, accreditation and tax regimes. It would do well for this wording to include the phrase: "This includes those achieved through improperly ..."; however, it doesn't mention it like that. 
It is considered that there is a reasonably expected economic benefit, when the taxpayer's operations seek to generate income, reduce costs, increase the value of the assets they own, improve their position in the market, among other cases. To quantify the reasonably expected economic benefit, contemporaneous information related to the operation under analysis will be considered, including the projected economic benefit, to the extent that such information is supported and reasonable. For the purposes of this article, the tax benefit will not be considered part of the reasonably expected economic benefit. (Fiscal Code of the Federation, 2020).

Perhaps the only reasonable paragraph in this article, describes the traits that justify the existence of the business reason.

The expression business reason will be applicable regardless of the laws that regulate the economic benefit reasonably expected by the taxpayer. The tax effects generated in terms of this article will in no case generate consequences in criminal matters. (Fiscal Code of the Federation, 2020).

It is clarified that the concept of business reason developed in this article is solely for tax purposes; and, furthermore, at least until now, there will be no criminal consequences, however ... this is just beginning...

\section{Article 69-B of the Fiscal Code of the Federation}

This material could not be considered complete without dealing with the fearsome article 69-B of the Federal Tax Code, which although it is not part of the 2020 reform, but already existed, with the maelstrom of regulations that are analyzed in this work, passed hurricane category 3 to category 5. Let's start with the analysis:

Article 69-B. When the tax authority detects that a taxpayer has been issuing vouchers without having the assets, personnel, infrastructure or material capacity, directly or indirectly, to provide the services or produce, market or deliver the goods that such vouchers cover, or that said taxpayers are not located, the non-existence of the operations covered by such vouchers will be presumed. (Fiscal Code of the Federation, 2020).
This first paragraph is forceful and conceptualizes the business reason perhaps without intending it; every time it tells us that if the elements do not exist to carry out any negotiation, and even so it issues vouchers, the operations supported by them are presumed nonexistent.

In this case, it will proceed to notify taxpayers who are in this situation through their tax mailbox, the Internet page of the Tax Administration Service, as well as through publication in the Official Gazette of the Federation, in order to that those taxpayers can declare before the tax authority what is convenient for them and provide the documentation and information they consider pertinent to distort the facts that led the authority to notify them. For this, interested taxpayers will have a period of fifteen days from the last of the notifications that have been made. (Fiscal Code of the Federation, 2020).

The means of notification are established, and once it has been made, there is fifteen days to provide the evidence that disproves the presumption of simulation.

Taxpayers may request through the tax mailbox, on a single occasion, an extension of five days to the period provided for in the previous paragraph, to provide the respective documentation and information, as long as the request for an extension is made within said period. The extension requested in these terms will be understood to be granted without the need for a pronouncement by the authority and will begin to be computed from the day following the expiration of the term provided in the preceding paragraph. (Fiscal Code of the Federation, 2020).

There is the possibility of requesting (approval not guaranteed), an extension of five more days to provide the evidence; provided that said request is made within the aforementioned fifteen days.

After the deadline for providing documentation and information and, where appropriate, the extension, the authority, within a period that will not exceed fifty days, will assess the evidence and defenses that have been asserted and notify the taxpayers of their resolution. respective through the tax mailbox. 
Within the first twenty days of this period, the authority may require additional documentation and information from the taxpayer, which must be provided within the period of ten days after the notification of the tax mailbox requirement takes effect. In this case, the aforementioned period of fifty days will be suspended from the date the notification of the request takes effect and will resume the day after the said period of ten days expires. Likewise, a list will be published in the Official Gazette of the Federation and on the Internet page of the Tax Administration Service, of the taxpayers who have not disproved the facts attributed to them and, therefore, are definitely in the situation at hand. referred to in the first paragraph of this article. In no case will this list be published before thirty days after notification of the resolution. (Fiscal Code of the Federation, 2020).

Once the proofs have been offered, the authority will assess and notify them within a period of no more than fifty days and will notify the taxpayer of its resolution. It establishes the possibility that the tax authority requires additional information, in this regard, it is necessary to keep track of the deadlines of both the authority to request and the taxpayer to provide the data, in order not to fall into illegalities. If the facts are not distorted, the name of the taxpayer will be published in the DOF and on the "infallible" SAT platform.

"The effects of the publication of this list will be to consider, with general effects, that the operations contained in the tax receipts issued by the taxpayer in question do not produce or produce any tax effect." (Fiscal Code of the Federation, 2020).

Accordingly, the pertinent one to consult said list with some frequency, since if the receipts issued by these taxpayers do not have tax effects, it may be that it is one of our suppliers and in this case, the deductions do not proceed. The tax authority will also publish in the Official Gazette of the Federation and on the Internet page of the Tax Administration Service, on a quarterly basis, a list of those taxpayers who manage to disprove the facts that are imputed to them, as well as those who obtained a resolution or sentence firm that have annulled the resolution referred to in the fourth paragraph of this article, derived from the means of defense presented by the taxpayer. (Fiscal Code of the Federation, 2020).
This provision can be dangerous for the taxpayer. While it is true that the authority seeks to make known those who were not guilty of simulation; meanwhile, he has already discredited them with the previous publication. It should be reconsidered and limited to publishing only those who, after the deadline, were unable to definitively disprove this assumption.

"If the authority does not notify the corresponding resolution, within a period of fifty days, the presumption regarding the observed tax receipts, which gave rise to the procedure, will be rendered ineffective." (Fiscal Code of the Federation, 2020).

The suggestion is to be very vigilant in calculating the days, in a strict sense, to day 51 , any presumption would be illegal.

Individuals or legal entities that have given any tax effect to the tax receipts issued by a taxpayer included in the list referred to in the fourth paragraph of this article, will have thirty days following the aforementioned publication to prove before the authority itself. , who actually acquired the goods or received the services covered by the aforementioned tax receipts, or will proceed within the same period to correct their tax situation, through the corresponding complementary declaration or declarations, which they must present in terms of this Code. (Fiscal Code of the Federation, 2020).

This paragraph confirms what was expressed in previous lines; It is evident that the receipts in such circumstances do not have fiscal effects and, if they do not prove the existence of the goods acquired or services provided; It will be necessary to present the returns that correct the tax situation for non-existent deductions. Here we have a serious problem to verify the existence of these operations, that is, if it is about goods, its purchase can be accredited, but what happens with the services? The services are intangible and could hardly be evidenced, when In effect, it has been said that it is appropriate to get used to designing service logs, progress reports or, desirably, some deliverable. In the event that the tax authority, using its powers of verification, detects that a natural or legal person did not accredit the effective provision of the service or acquisition of the goods, or did not correct their tax situation, in the terms provided for in paragraph above, will determine the corresponding tax credit (s).

BÁRCENAS-PUENTE, José Luis \& ANDRADE-OSEGUERA, Miguel Ángel. The business reason in the 2020 tax reform. Journal-Business Administration -Marketing; Accounting. 2020 
Likewise, the operations covered by the aforementioned tax receipts will be considered as acts or simulated contracts for the purposes of the crimes provided for in this Code. (Fiscal Code of the Federation, 2020).

This paragraph establishes the commission of tax crimes, both for those who issued receipts without having the necessary elements (business reason), and for those who received them and made deductions with them. In practice, the former are known as "EFOS" (companies that invoice simulated operations, or simply "invoices"), and the latter, as "EDOS" (companies that deduct simulated operations).

To have the complete reference, let us remember that there is also an article 69-B Bis that deals with the undue transmission of tax losses; and a new article 69-B Ter for 2020, which establishes the existence of "third party tax collaborators", a figure that consists in that a person who has information that proves the existence of simulated operations, can collaborate with the tax authority to pursue the crime, reserving your identity, something like a "tax protected witness".

\section{The influence of international audit measures on the 2020 tax reform.}

In summary, the influence of international tax measures on this reform is set out below:

In order to avoid double taxation or even international treaties that are "aggressive" for the parties, one of the recommendations of the OECD and the G20 was to modify the content of international treaties to avoid the use of hybrid instruments, the so-called treaty shopping and artificially avoiding the creation of a permanent establishment; Therefore, it is important to apply these recommendations in an orderly manner and to consider the design of an instrument that collects them in such a way as to avoid the treaties being negotiated bilaterally. (KPMG Cárdenas Dosal, SC, 2019).

According to this, it is a matter of stopping, by recommendations of the OECD and the G20, the celebration of international treaties that allow the resident of a third State to constitute a legal entity in one of the two contracting countries to benefit from the Treaty.
Treaty shopping can be translated as "treaty purchase." This is what the reform in article 2 of the LISR refers to the concept of permanent establishment.

Arguing the final report of Action 4 of the BEPS project and considering that said report considers that establishing limits to the deduction of interest is more effective than the thin capitalization rules to avoid the erosion of the base through the use of debt mechanisms, It is proposed that the deduction of net interest (interest accrued in favor and interest accrued as a charge) may not exceed $30 \%$ of the adjusted tax profit. If interest cannot be deducted in one year, it can be deducted in the next 10 years, meeting certain requirements. (KPMG Cárdenas Dosal, SC, 2019).

Let us remember that the BEPS Project:

It is the name that has been given to the Erosion of the Base and Location of Utilities, literal translation; In other words, we could consider the decrease in the tax base in companies due to the transfer of profits from one country to another. The OECD has detected that capital and assets are transferred to countries with low taxation, becoming a serious problem. (Bárcenas Puente, 2019).

In this way, the BEPS Project, in its 15 actions, tries to combat fiscal practices that damage collection. In the specific case of action 4 in comment, it seeks to limit the deduction of interest.

The adjusted tax profit will be the tax plus the accrued interest and the investment deduction, a kind of tax EBITDA. It is important to mention that in the case of suffering a tax loss in the year, it will be subject to what the tax authorities indicate through general rules, which is highly criticizable. (KPMG Cárdenas Dosal, SC, 2019).

The composition of an adjusted tax profit is exposed, a new concept in our laws.

Interest not deducted in one year may be deducted in the next three, with an exception for the first MXN 20 million (mdp); however, this amount is at the group level, and can be consolidated for the purposes of this deduction according to the rules that will be issued. 
This provision will be applicable to deductible interest as of financial year 2020 regardless of the debts that give rise to the interest from previous years. Among the exceptions for this deduction, we can mention the debts contracted to finance public infrastructure works, construction of real estate, and productive state companies. (KPMG Cárdenas Dosal, SC, 2019).

This is the influence of international tax provisions, on the part of the OECD and the G20, in this 2020 reform; same that began in 2019 with the establishment of the BEPS Project, fighting, in general, any fiscal planning strategy.

\section{Tax advice as a crime in the 2020 tax reform}

On October 15, 2019, the Decree that amended, added and repealed various provisions of the Federal Law Against Organized Crime, the National Security Law, the National Code of Criminal Procedures, was published in the Parliamentary Gazette, of the Fiscal Code of the Federation and of the Federal Penal Code.

In this regard, the following comments are extracted:

It will be considered that they are threats to national security and, therefore, that the issuance, sale, disposal, purchase or acquisition of tax receipts that protect non-existent, false operations or simulated legal acts in accordance with article 113 BIS of the Federal Tax Code (CFF), exclusively when the figures, quantity or value of the tax receipts that cover non-existent, false operations or simulated legal acts, exceed three times what is established in article 108, section III of the CFF, that is, when they are greater than the amount of $\$ 7,804,230$. (EY Mancera, SC, 2019).

Given such seriousness, it is necessary to review the aforementioned article 113-Bis of the $\mathrm{CFF}$, to continue with the analysis:

Article 113 Bis.- A sanction of two to nine years in prison will be imposed on anyone who, by himself or through a third party, issues, transfers, buys or acquires tax receipts that cover non-existent, false operations or simulated legal acts.
Anyone who knowingly allows or publishes, through any means, advertisements for the acquisition or disposal of tax receipts that protect non-existent, false operations or simulated legal acts will be sanctioned with the same penalties. When the crime is committed by a public servant in the exercise of his functions, he will be dismissed from his job and disqualified from one to ten years to carry out a public position or commission, in addition to the aggravating circumstance indicated in article 97 of this Code. A complaint will be required by the Ministry of Finance and Public Credit, to proceed criminally for this crime. The crime provided for in this article, as well as the one provided in article 400 Bis of the Federal Penal Code, may be prosecuted simultaneously. (Fiscal Code of the Federation, 2020).

This is the aforementioned foundation, which, in turn, refers to article $400 \mathrm{Bis}$ of the Federal Criminal Code, which provides:

Article 400 Bis. From five to fifteen years in prison and a fine of one thousand to five thousand days shall be imposed on anyone who, by himself or through a third party, performs any of the following behaviors:

I. Acquire, transfer, manage, custody, possess, exchange, convert, deposit, withdraw, give or receive for any reason, invest, transfer, transport or transfer, within the national territory, from it to abroad or conversely, resources, rights or assets of any nature, when you are aware that they come from or represent the product of an illegal activity, or

II. Hides, conceals or attempts to conceal or conceal the nature, origin, location, destination, movement, property or ownership of resources, rights or goods, when it is aware that they come from or represent the product of an illegal activity.

For the purposes of this Chapter, it shall be understood that resources, rights or assets of any nature are the product of an illicit activity, when there are well-founded indications or certainty that they come directly or indirectly, or represent the profits derived from the commission of a crime. and its legitimate origin cannot be proven. 
In the case of conduct provided for in this Chapter, in which the services of institutions that make up the financial system are used, a prior complaint from the Ministry of Finance and Public Credit will be required to proceed criminally.

When the Ministry of Finance and Public Credit, in exercise of its oversight powers, finds elements that allow presuming the commission of any of the crimes referred to in this Chapter, it must exercise with respect to them the powers of verification conferred by the laws and Report the facts that are likely to constitute such crimes. (Federal Penal Code, 2020).

That is to say, we are in the presence of both punitive spheres, the administrative one that takes criminal powers to establish, as has always been criticized, crimes that merit corporal punishment; and the merely criminal, established in the respective code; being able to carry simultaneously.

Now, as regards the surplus of three times the amount established in section III of article 108 of the CFF, it corresponds to the Federal Law against Organized Crime, in the following terms:

Article 2.- When three or more people are in fact organized to carry out, permanently or repeatedly, behaviors that, by themselves or in conjunction with others, have the purpose or result of committing one or more of the following crimes, they will be punished for that alone In fact, as members of organized crime:

(...) VIII Ter. The conducts provided for in article 113 Bis of the Federal Tax Code, exclusively when the figures, quantity or value of the tax receipts that cover non-existent, false operations or simulated legal acts, exceed 3 times what is established in section III of article 108 of the Fiscal Code of the Federation; (...) (Federal Law against Organized Crime, 2020).

So far we have talked about the issuance of vouchers that cover simulated operations, the fiscal and criminal repercussions for whoever issues and who receives, and its classification as organized crime. But what are the effects of tax advice? Hardly any public accountant or lawyer versed in the matter will advise his client to buy false invoices, since they are gross illicit acts whose professional ethics he pursues and points out.
However, as part of various strategies, there is the design of legal acts that will have as their purpose the reduction, elimination or deferral of the tax burden, what we call tax planning and whose concept has been aired on several occasions by a server; However, for the tax authority, as seen in the concept of business reason, it should also be considered illegal, because it harms the interests of the treasury.

Under this irrational context of the tax authority, we must add that tax crimes are not limited to the issuance and receipt of false receipts, but to any action that undermines tax collection. Thus, there is talk of tax crimes in general in article 95 of the Federal Tax Code, making the following actors responsible:

Article 95.- They are responsible for tax crimes, who:

(...) IX. Derived from a contract or agreement that implies the development of independent activity, propose, establish or carry out, by themselves or through a third party, acts, operations or practices, whose execution directly derives the commission of a tax crime. (Fiscal Code of the Federation, 2020).

It can be noted that this is the fraction that places us as tax advisers in the case of participants in the commission of a tax crime in general, beyond the specific matter of EDOS and EFOS.

What kind of responsibility do we have?

In addition to being subject to the corporal sanction already mentioned when being involved in this section IX of the aforementioned article 95 of the CFF, there is also a considerable economic sanction, in the following terms:

Article 82-A. The following are offenses related to the disclosure of reportable schemes committed by tax advisors:

I. Do not disclose a reportable scheme, disclose it incompletely or with errors, or do so extemporaneously, unless it is done spontaneously. The information is considered to be incomplete or presented with errors, when the lack of that information or the incorrect data substantially affect the analysis of the reportable scheme. 
II. Do not disclose a general reportable scheme, which has not been implemented.

III. Failure to provide the identification number of the reportable scheme to taxpayers in accordance with article 202 of this Code.

IV. Failure to comply with the request for additional information made by the tax authority or falsely state that it does not have the information required regarding the reportable scheme in the terms of article 201 of this Code.

V. Failure to issue any of the records referred to in the seventh paragraph of article 197 of this Code.

SAW. Failure to inform the Tax Administration Service of any change that occurs after the disclosure of the reportable scheme in accordance with the provisions of the penultimate paragraph of article 202 of this Code. Likewise, submit extemporaneously, unless it is done spontaneously, the information indicated in sections VI, VII and VIII of article 200 of this Code.

VII. Failure to present the informative return that contains a list with the names, denominations or company names of the taxpayers, as well as their code in the federal registry of taxpayers, to whom they provided tax advice regarding the reportable schemes, referred to in the article. 197 of this Code. (Fiscal Code of the Federation, 2020).

Before reviewing what the reportable schemes are (in the next section), let's see the sanctions corresponding to these infractions:

Article 82-B. Whoever commits the infractions related to the disclosure of reportable schemes provided for in article $82 \mathrm{~A}$, the following sanctions will be imposed:

I. From $\$ 50,000.00$ to $\$ 20,000,000.00$ in the case provided in section I.

II. From $\$ 15,000.00$ to $\$ 20,000.00$ in the assumption provided in section II.

III. From $\$ 20,000.00$ to $\$ 25,000.00$ in the assumption provided in section III.

IV. From $\$ 100,000.00$ to $\$ 300,000.00$ in the case provided in section IV.
V. From $\$ 25,000.00$ to $\$ 30,000.00$ in the case provided in section $\mathrm{V}$.

SAW. From $\$ 100,000.00$ to $\$ 500,000.00$ in the case provided in section VI.

VII. From $\$ 50,000.00$ to $\$ 70,000.00$ in the case provided in section VII. (Fiscal Code of the Federation, 2020).

We see then that there is a whole range of infractions and their consequent financial sanctions in relation to non-compliance with the so-called reportable schemes. Finally, before reviewing this new concept, let's look at the limited definition that is made in the CFF of "tax advisers", as shown below:

Article 197. (...) A tax advisor is understood to be any natural or legal person who, in the ordinary course of his activity, performs tax advisory activities, and is responsible for or is involved in the design, marketing, organization, implementation or administration of the entire reportable scheme or who makes the entire reportable scheme available for implementation by a third party. The limited definition of the definition can be appreciated, limiting it to the realization of a reportable scheme.

\section{Reportable schemas}

Let's review this new concept:

Article 199. A reportable scheme is considered to be any that generates or may generate, directly or indirectly, obtaining a tax benefit in Mexico and has any of the following characteristics:

I. Prevent foreign authorities from exchanging tax or financial information with Mexican tax authorities, including by applying the Standard for the Automatic Exchange of Information on Financial Accounts in Tax Matters, referred to in the recommendation adopted by the Council of the Organization for Economic Cooperation and Development on July 15, 2014, as well as other similar forms of information exchange. In the case of the referred Standard, this section will not be applicable to the extent that the taxpayer has received documentation from an intermediary that shows that the information has been disclosed by said intermediary to the foreign tax authority in question.

BÁRCENAS-PUENTE, José Luis \& ANDRADE-OSEGUERA, Miguel Ángel. The business reason in the 2020 tax reform. Journal-Business Administration -Marketing; Accounting. 2020 
The provisions of this section include when an account, financial product or investment that is not a financial account is used for the purposes of the referred Standard or when income or capital is reclassified in products not subject to information exchange.

II. Avoid the application of Article 4-B or Chapter I, Title VI, of the Income Tax Law.

III. It consists of one or more legal acts that allow the transmission of tax losses pending reduction of tax profits, to people other than those who generated them.

IV. It consists of a series of interconnected payments or operations that return all or part of the amount of the first payment that is part of said series, to the person who made it or one of its partners, shareholders or related parties.

V. Involve a resident abroad who applies an agreement to avoid double taxation signed by Mexico, regarding income that is not taxed in the country or jurisdiction of tax residence of the taxpayer. The provisions of this section will also be applicable when said income is taxed at a reduced rate compared to the corporate rate in the country or jurisdiction of tax residence of the taxpayer.

SAW. Involve transactions between related parties in which:

a) Intangible assets difficult to value are transferred in accordance with the Guidelines on Transfer Pricing for Multinational Companies and Tax Administrations, approved by the Council of the Organization for Economic Cooperation and Development in 1995, or those that replace them. An intangible difficult to value is understood to be when, at the time the operations are carried out, there are no reliable comparables or the projections of future flows or income expected to be obtained from the intangible, or the assumptions for its valuation, are uncertain, therefore it is difficult to predict the final success of the intangible at the time it is transferred; b) Business restructurings are carried out, in which there is no consideration for the transfer of assets, functions and risks or when as a result of said restructuring, the taxpayers who pay taxes in accordance with Title II of the Income Tax Law, reduce your operating profit by more than $20 \%$. Business restructurings are referred to in the Transfer Pricing Guidelines for Multinational Companies and Tax Administrations, approved by the Council of the Organization for Economic Cooperation and Development in 1995, or those that replace them;

c) The temporary use or enjoyment of goods and rights is transferred or granted without consideration in exchange or services are provided or functions are performed that are not remunerated;

d) There are no reliable comparables, as they are operations that involve unique or valuable functions or assets, or

e) A unilateral protection regime granted in terms of foreign legislation is used in accordance with the Guidelines on Transfer Pricing for Multinational Companies and Tax Administrations, approved by the Council of the Organization for Economic Cooperation and Development in 1995 , or those that replace them.

VII. It is avoided to constitute a permanent establishment in Mexico in terms of the Income Tax Law and the treaties to avoid double taxation signed by Mexico.

VIII. It involves the transfer of a fully or partially depreciated asset, which allows its depreciation by another related party.

IX. When it involves a hybrid mechanism defined in accordance with section XXIII of article 28 of the Income Tax Law.

$X$. Avoid the identification of the beneficial owner of income or assets, including through the use of foreign entities or legal figures whose beneficiaries are not designated or identified at the time of its incorporation or at any later time. 
XI. When there are tax losses whose term for reducing the tax profit is about to end in accordance with the Income Tax Law and operations are carried out to obtain tax profits to which said tax losses are reduced and said operations generate a Deduction authorized to the taxpayer who generated the losses or to a related party.

XII. Avoid the application of the additional $10 \%$ rate provided for in articles 140 , second paragraph; 142, second paragraph of section V; and 164 of the Income Tax Law.

XIII. In which the temporary use or enjoyment of an asset is granted and the lessee in turn grants the temporary use or enjoyment of the same asset to the lessor or a related party of the latter.

XIV. It involves operations whose accounting and tax records present differences greater than $20 \%$, except those that arise due to differences in the calculation of depreciation.

For the purposes of this Chapter, a scheme is considered to be any plan, project, proposal, advice, instruction or recommendation expressed expressly or tacitly in order to materialize a series of legal acts. The carrying out of a procedure before the authority or the defense of the taxpayer in tax controversies is not considered a scheme.

Generalized reportable schemes are understood as those that seek to be massively marketed to all types of taxpayers or to a specific group of them, and although they require minimal or no adaptation to adapt to the specific circumstances of the taxpayer, the way to obtain the tax benefit is the same. Custom reportable schemes are understood to be those that are designed, marketed, organized, implemented or administered to adapt to the particular circumstances of a specific taxpayer.

The Tax Administration Service will issue general rules for the application of the previous paragraphs. The Ministry of Finance and Public Credit by means of a secretarial agreement will issue the parameters on minimum amounts with respect to which the provisions of this Chapter will not apply.
For the purposes of this Chapter, the monetary value derived from any of the assumptions indicated in the fifth paragraph of article 5-A of this Code is considered a tax benefit.

Additionally, any mechanism that avoids the application of the previous paragraphs of this article, in the same terms indicated in this Chapter, will be reportable. (Fiscal Code of the Federation, 2020).

We can see that it is a whole compendium of actions, all tending to avoid any reduction, elimination or deferral of the payment of contributions, whether lawful or not, as already mentioned. In this sense, the tax advisor, in addition to conditioning his professional practice to the risk of being criminally classified as organized crime, under these parameters, must expose his client, revealing any of these facts.

\section{Conclusions}

You can conclude the following:

a) The business reason concept must be taken from the financial reporting standards. Article 5-A of the Federal Tax Code is the starting point in this 2020 model inspection apparatus; it limits itself to saying that there is a business reason when the tax benefit is greater than the economic one; its wording is unfortunate since it seems to include deductions, credits and regime changes as part of such benefits.

b) Article 69-B of the same code, already in force previously, takes on special importance this year, by establishing the bases to convict and expose the EFOS and EDOS.

c) For their part, the OECD and the G20 intensify the application of the BEPS Project in the 2020 tax reform, limiting tax planning at the international level.

d) As a garnish to this inspection salad, tax consultancy is criminalized, not only in the case of issuing vouchers that cover simulated operations, but also as part of tax crimes in general; it is considered, along with the taxpayer, that the tax advisor participates in a crime that in legal terms is equated with organized crime. 
e) Additionally, it is established as an obligation for tax advisers, to comply with various obligations in the matter of what is called "reportable schemes", that is, those activities, carefully detailed, that in various ways cause damage to the national treasury and / or international. In general, the Treasury intends to disclose to customers.

\section{References}

Bárcenas Puente, J. L. (2019). El Proyecto BEPS y la planeación fiscal. Aplicaciones del Derecho, 37-50.

Código Fiscal de la Federación. (2020). México: Tax Editores.

Código Penal Federal. (2020). México: Porrúa, Hnos.

Consejo Mexicano de Normas de Información Financiera, AC. (2020). Normas de Información Financiera. México: CINIF / IMCP.

EY Mancera, SC. (18 de Octubre de 2019). EY tax flash. Obtenido de http://www.eyboletin.com.mx/eysite2/pdf/come ntarios_3198.pdf

IKPMG Cárdenas Dosal, SC. (20 de Diciembre de 2019). KPMG México. Obtenido de https://home.kpmg/mx/es/home/tendencias/201 9/12/reforma-fiscal-2020

Ley Federal contra la Delincuencia Organizada. (2020). México: Porrúa Hnos. 